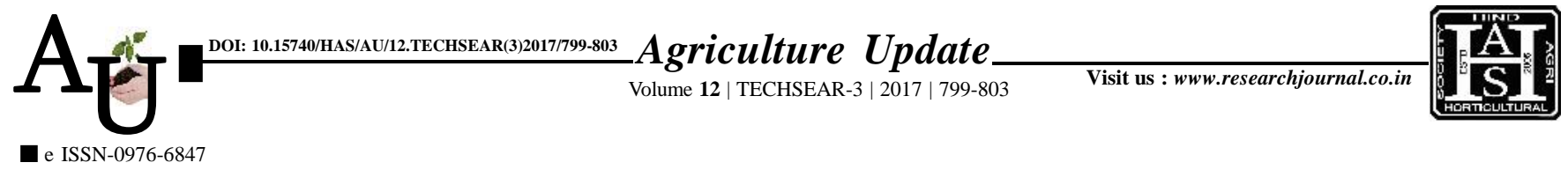

\title{
Research Article: Feeding practices adopted for cattle in sugarcane pockets of Nanded district
}

Article Chronicle: Received :

13.07.2017;

Accepted :

28.07.2017

KEY WORDS:

Cattle, Feeding

practices, Sugarcane

pockets
Author for correspondence :

\section{S.S. GHUGE}

Department of Animal Husbandry and Dairy

Science, College of

Agriculture, Vasantrao

Naik Marathwada Krishi

Vidyapeeth,, PARBHANI

(M.S.) INDIA

See end of the article for

authors' affiliations

\section{S.S. GHUGE, D.V. BAINWAD AND B.M. THOMBRE}

SUMMARY : The present investigation entitled "Feeding practices adopted for cattle in sugarcane pockets of Nanded district" was undertaken to study the different package of practices followed for indigenous and crossbred cattle. Twenty villages of sugarcane pockets of Nanded district were selected with the objective to study feeding practices of cattle. The data was collected from the 200 respondents in four sugarcane pockets. The study revealed that the indigenous cattle is mostly used for the draft purpose. The population of females are more than that of male one. Green fodder is mostly available in Kharif and Rabi season. It is also available in summer, where there is ample quality water is available, as most of the area in Jai shiv shankar co- operative sugarcane pockets was dry land. Grazing + stall feeding was adopted as method of feeding by majority of the respondents. There was very few farmers who adopted urea treatment and silage preparation. Inadequate availability of green fodder, high cost of fodder and inadequacy of own grazing land are some feeding constraints.

How to cite this article : Ghuge, S.S., Bainwad, D.V and Thombre, B.M. (2017). Feeding practices adopted for cattle in sugarcane pockets of Nanded district. Agric. Update, 12(TECHSEAR-3) : 799-803; DOI: 10.15740/ HAS/AU/12.TECHSEAR(3)2017/799-803. 